\title{
CAIN Capitalism, Human Rights, SHELLEY and Critical Theory
}

\author{
David Ingram (2018) World Crisis and Underdevelopment: A Critical \\ Theory of Poverty, Agency and Coercion. Cambridge: Cambridge \\ University Press.
}

As with many areas of political theory, the global justice debate has thus far often been dominated by an ideal-theoretical approach that works firmly within the liberal tradition. David Ingram's World Crisis and Underdevelopment: A Critical Theory of Poverty, Agency and Coercion certainly shares much with this existing literature, insofar as it aims to provide both a normative evaluation of various injustices affecting the global order, and also a number of utopian prescriptions for institutional changes capable of rectifying them. But there are two key features of Ingram's critical theory-inspired approach that he claims distinguish his contribution from existing work within this dominant tradition. First, Ingram aims to provide a somewhat novel normative grounding for the evaluation of global injustice, rooted in work from the second and third generation Frankfurt School. Second, the book intends to place global capitalism at the very centre of its analysis, framing it as both the chief producer of global injustices, and the primary obstacle to be overcome in moving beyond them. What arguments does Ingram mount in the service of these self-confessed 'ambitious aims' (2018: 16)? And how successful ultimately is World Crisis and Underdevelopment in achieving them?

Following Axel Honneth, Chapter One argues that individual agency (the capacity to act intentionally) is socially sustained, and thus dependent on recognition from others. Ingram is keen to acknowledge, in line with a number of recent critiques of the theory of recognition, that this can have regressive (and not just progressive) possibilities, frustrating the development of agency by forcing individuals to abide by 'oppressive social norms' (2018: 86). But he is ultimately clear that individuals need to belong to a community of mutual recognition to be free, as this provides them with important goods such as self-respect and self-esteem. Stressing the significance of the wider social environment in this way allows Ingram to highlight how a variety of social 
pathologies, such as accelerating climate change, (political, social, economic) inequality, and discrimination of all kinds prohibit the development of adequate individual agency. This foundational chapter then enables the book to move on, in Chapter Two, to offer a critique of what Ingram takes to be the current ruling policy paradigms of global development. Whilst more welfare-oriented development policy certainly recognizes the coercive nature of the global economy, Ingram claims that the paternalistic, 'trickle down'-inspired policies this paradigm tends to promote inadvertently 'engender their own varieties of agency-stunting coercion' by creating dependency, social alienation, low selfesteem and political apathy (2018: 87). This dominant kind of development policy thus fails to recognize the importance of properly empowering the victims of global poverty for overcoming injustice.

Chapter Three also applies this underlying social-recognition framework, but this time to the often-polarized debate surrounding justice in migration. Here Ingram critiques both open border cosmopolitan accounts for ignoring 'the importance of communal attachments for fostering social recognition and intact identity' (2018: 153) and communitarian accounts for exaggerating 'the importance of stability, harmony, and homogeneity' (2018: 156). Inspired by the discourse ethics of Jürgen Habermas, these opening chapters also prescribe a number of changes to the global order, all of which ultimately stress the need for far more collective deliberation and dialogical (rather than monological) reasoning. For Ingram, 'dialogical critique involving both the poor and their academic and governmental interlocuters' (2018: 113) is the only way to prevent flawed development strategies in the future, allowing victims of injustice to disclose the coercion to which they have been subjected. And decision-making regarding the admission policies for migrants and refugees ought to follow a similar strategy, involving applicants and current members in an inclusive discussion.

Provided one can ignore in these early chapters the occasional uncharitable portrayal of John Rawls - Ingram charges Rawls at one point with providing the 'background justifications' for the ruling paradigm of global development that he seeks to critique (2018: 101), without providing any empirical evidence for his claim that development policy-makers were really inspired by this Rawlsian view, or indeed that the Rawlsian framework is really supportive of anything resembling trickle-down - these early chapters certainly succeed in demonstrating the value of applying the normative insights of the Frankfurt School to the question of global justice. But it is perhaps Chapter Four, where Ingram moves on to directly tackle his second aim, that of giving pride of place to global capitalism in his evaluation of global injustice, that the book really 
comes into its own. Here Ingram defends the view that overcoming global injustice is ultimately going to have to involve the abolition of capitalism. Currently, developed capitalist countries can use international institutions to impose 'costs on poorer, less powerful nations while extracting advantages for themselves' (2018: 182), and the supposedly neutral phrases like 'efficiency', 'growth' and 'free' trade that legitimate this state of affairs 'abstract from the environmental, ecological, social and political costs of market exchange' (2018: 212). Consequently, Ingram proposes as an alternative to this capitalist status quo a fair (rather than 'free') international trade system and a form of democratic socialism that still makes extensive use of markets, but where capital is publicly owned so that 'those who own controlling shares of businesses' can no longer 'dictate terms of investment, production, and employment to the rest of us' (2018: 217).

This extensive discussion of the coercive and unaccountable nature of much of the global economy, leads Ingram, in Chapter Five, to consider what the normative basis for the international laws capable of reigning in global capitalism might be. Ingram argues that it is an extension, and radicalization of existing conceptions of human rights (that includes rights to democracy and a stable natural environment, for instance) that can best serve this role. Arguing against a narrow interpretation of human rights and defending his own expanded conception from the charge that it is inflationary, Ingram follows Habermas in claiming that there is an 'indivisibility' between civil, social, economic and cultural rights, and they each work only in collaboration (2018: 246).

Conceding that an expanded realm of international legal authority would be required to properly enforce these radicalized human rights, and prevent them being respected by nation states only when they advanced rather than obstructed other aims such as economic growth, Chapter Six proposes the reconstitution of the United Nations General Assembly 'as a quasi-legislative body' (2018: 287) to better enable the holding to account of nation states. Coupled with an international 'supreme court of appeal or a constitutional court' to guard against the 'danger of discriminating against stateless refugees, undocumented migrants, ethnic minorities' and so on, this is said to represent a more feasible aim than the creation of a (potentially dangerous) world state (2018: 304). This line of reasoning of course raises the question of the legitimacy of attempts to expand the realm of international authority, so Ingram adopts an argument from Alan Buchanan to defend the view that international human rights laws 'need only derive their democratic legitimation' from national, domestic democratic systems (2018: 272). Because the reconstituted General Assembly would only be regulative and adjudicative, it need not be as directly 
democratically accountable as national parliaments, but would, Ingram claims, still represent a vast improvement on the current - largely unaccountable and powerless - system.

These later chapters certainly begin to make good on Ingram's aim to place global capitalism at the very center of global justice theorizing, providing the reader with both a compelling normative evaluation of the existing global economy and a series of far-reaching potential changes to it that would appear to vastly improve upon things as they currently stand. However, aside from scattered references to the need for a 'popular mandate' (2018: 217, fn.69) to implement these radical changes and the importance of 'fostering grass-roots social movements' for achieving this (2018:261, fn.49), Ingram is disappointingly silent on one particularly crucial question: what kinds of collective political agents and actions might be capable of actually challenging this capitalist status quo and beginning to usher in the future he describes? Ingram might respond that it is unfair to criticize an already rather long book for failing to include discussion of yet more issues. But given that he begins the book by explicitly adopting Marx's description of the aim of critical theory as 'the self-clarification of the struggles and wishes of the age' (2018: 29), and clearly conceives of political philosophy 'primarily as a vehicle for political practice' (2018: xviii), this would be a far from satisfactory response. Ingram's indebtedness to the critical theory tradition makes his decision to prioritize end-state utopian theorizing and his relative silence on questions of political action and agency in our decidedly non-ideal present circumstances genuinely surprising. There are scores of issues (such as the desirability of economic growth, free trade, state intervention in the economy, and the legitimacy of international institutions) on which a huge degree of politicization and persuasion would need to take place before Ingram's chosen vision could be enacted. If a concern of the book is to theorize chiefly in the service of real social movements, providing orientation to aid the struggles of global justice activists, why not consider how this might best be achieved?

Admittedly, Ingram does dedicate his final chapter to the question of whether the expansion of global solidarity that is the 'ultimate prerequisite' for the changes he prescribes is actually possible (2018: 312 ), and thus is clearly aware of the importance of this consideration. But aside from a rather brief discussion defending the plausibility of cosmopolitan solidarity arising out of local struggles against specific, regional threats, the question of overcoming any of the many obstacles to this solidarity is only really gestured towards. And yet Ingram himself describes his assessment of the prospects for solidarity of this kind being fostered as 'guardedly optimistic' (2018: xviii). But I at least 
did not finish the book with this same sense of optimism. The vast majority of the recommendations made in the course of the book ultimately seem somewhat disconnected from the immediate and medium-term concerns of those struggling against the existing global order, given that many are currently fighting a rear-guard battle just to defend the remaining progressive elements of an inadequate and collapsing social democracy against a resurgent nativist right. Specific guidance and orientation to real political agents in the course of the book doesn't stretch much beyond instructing global justice activists to 'reimagine themselves as future cosmopolitan citizens' with 'a hope bordering on religious fervor' (2018: 343). This is not to deny that there is a place and indeed a need for ideal and utopian theorizing, but it seems strange to explicitly flout one's commitment to practically aiding the 'struggles of the age' and then stick so resolutely to offering guidance at such a removed and utopian level. One can only hope that future work in this area takes as its central focus some of the concrete steps that might be pursued in effectively responding to the 'rapacious form of global capitalism' (2018: 339) Ingram critiques so extensively.

Overall however, whilst the clarification offered by World Crisis and Underdevelopment may very well be of a more limited value to real social movements than Ingram at times seems to suggest, and there are some minor complaints about Ingram's portrayal of Rawls, World Crisis and Underdevelopment still undoubtedly represents a wide-ranging contribution to the literature, that succeeds in showing the continued vitality of global justice theorizing in general and of critical theory's importance to it more specifically.

Cain Shelley

PhD Candidate in Political Theory

Department of Government

London School of Economics and Political Science

email:c.b.shelley@lse.ac.uk

\section{- the global justicenetwork}

